\title{
A bioinformatics approach for exploring and identification of potential target genes of miR-130a-3p in doxorubicin-associated cardiotoxicity
}

\author{
Doksorubisin ile ilişkili kardiyotoksisitede miR-130a-3p'nin potansiyel hedef genlerinin \\ araştırllması ve tanımlanması için biyoinformatik bir yaklaşım
}

\author{
Hamid CEYLAN ${ }^{* 1, a}$ \\ ${ }^{I}$ Atatürk University, Science Faculty, Department of Molecular Biology and Genetics, 25240, Erzurum, Turkey
}

\begin{tabular}{|c|c|c|}
\hline • Geliş tarihi / Received: 18.12 .2020 & • Düzeltilerek geliş tarihi / Received in revised form: 27.05 .2021 & - Kabul tarihi / Accepted: 13.06 .2021 \\
\hline
\end{tabular}

\begin{abstract}
Doxorubicin (DOX) is considered one of the most effective chemotherapy drug and is used to treat many types of cancer. On the other hand, the effectiveness of this drug is restricted due to its adverse effects such as cardiotoxicity. However, the exact mechanism of DOX-induced cardiotoxicity has not been fully understood. To better understand the molecular mechanism of DOX-induced cardiotoxicity, this study focused on identifying a heart-specific miRNA and its target genes in the heart. Publicly available data was downloaded from the Gene Expression Omnibus (GEO) database, and differentially expressed genes (DEGs) were extracted by using the online bioinformatics tool iPathwayGuide. Using eight different prediction tools, target genes of miR-130a-3p were identified. Gene ontology (GO) and Kyoto Encyclopedia of Genes and Genomes (KEGG) pathway enrichment analyses were performed for DEGs intersected with miR-130a-3p targets. Among the HF and non-HF groups, a total of 29 DEGs targeted by miR-130a-3p were identified. We found that SLC8A1, which is among the intersecting genes, might be a crucial gene that is shaped in impaired myocardial function and cardiotoxicity. In conclusion, the findings of the study provided new insights into the potential targets for DOXinduced cardiotoxicity diagnosis, treatment, and/or attenuation.
\end{abstract}

Keywords: Bioinformatics analysis, Cardiotoxicity, Differentially expressed genes, Doxorubicin, microRNA

$\ddot{\partial} z$

Doksorubisin (DOX), en etkili kemoterapi ilaçlarından biri olarak kabul edilmekte ve birçok kanser türünü tedavi etmek için kullanılmaktadır. Öte yandan, bu ilacın etkinliği, kardiyotoksisite gibi olumsuz yan etkileri nedeniyle sinırlıdır. Bununla birlikte, DOX kaynakl kardiyotoksisitenin kesin mekanizması tam olarak anlaşılmamıştır. Bu çalışmada, İlaca bağlı kardiyotoksisitenin moleküler mekanizmasını daha iyi anlamak için kalbe özgü bir miRNA'yı ve kalpteki hedef genlerini belirlemeye odaklanmıştır. Herkese açı veriler, Gene Expression Omnibus (GEO) veri tabanından indirildi ve farklı şekilde ifade edilen genler (DEG'ler), çevrimiçi biyoinformatik aracı iPathwayGuide kullanilarak belirlendi. Sekiz farklı tahmin aracı kullanılarak miR-130a-3p'nin hedef genleri belirlendi. miR-130a-3p hedefleriyle kesişen DEG'ler için gen ontolojisi (GO) ve Kyoto Encyclopedia of Genes and Genomes (KEGG) yolu zenginleştirme analizi yapuldr. Kalp yetmezliği (HF) olan ve HF olmayan gruplar arasında, aynı zamanda miR-130a-3p'nin de hedefi olan toplam 29 DEG tespit edildi. Kesişen genler arasinda yer alan SLC8A1'in bozulmuş miyokardiyal fonksiyon ve kardiyotoksisitede şekillenen çok önemli bir gen olabileceğini bulundu. Çalışmanın bulguları, DOX kaynaklı kardiyotoksisitenin teşhisi, tedavisi ve / veya azalttlması için potansiyel hedeflere yeni bilgiler sağlamaktadır.

Anahtar kelimeler: Biyoinformatik analiz, Kardiyotoksisite, Farkll şekilde ifade edilen genler, Doksorubisin, mikroRNA

\footnotetext{
${ }^{*}$ Hamid CEYLAN; hamid.ceylan@ atauni.edu.tr; Tel: (0442) 23144 51; orcid.org/0000-0003-3781-4406
} 


\section{Introduction}

Doxorubicin (DOX), an anthracycline family member anti-cancer drug, is a widely used highly effective chemotherapeutic agent to treat a variety of cancers such as lymphomas (Luminari et al., 2011), lung cancer (Melguizo et al., 2015), breast cancer (Gennari et al., 2008), and many other tumor types. Unfortunately, in addition to its definite therapeutic effect, the clinical use of DOX is limited by significant adverse reactions. Cardiotoxicity is one of the most important dosedependent progressive and irreversible risks of DOX chemotherapy (L. Zhao \& Zhang, 2017). Cardiotoxicity, defined as "toxicity affecting the heart" by the National Cancer Institute (NCI), can occur even years after DOX administration and is among the leading cause of treatment-associated death in cancer survivors (Hooning et al., 2007; McGowan et al., 2017; Volkova \& Russell, 2011). Although multiple factors have been suggested, the precise biological mechanisms underlying DOX associated cardiotoxicity remain cloudly because it multi-step and biological process, but most studies indicate that ion homeostasis (Chaudhari et al., 2016), mitochondrial disruption (Wallace, 2007), and free radicals (Songbo et al., 2019) are involved. As a consequence, there are no therapeutic strategies with confirmed effectiveness for doxorubicin-induced cardiotoxicity (Chang et al., 2019).

MicroRNAs (miRNAs) are a class of endogenous small (18-23 nucleotides in length) noncoding RNAs. They regulate gene expression mainly by matching the $3^{\prime}$ untranslated region (3'-UTR) of target genes, either completely or partially (Deiuliis, 2016; Gomez et al., 2016). miRNAs, exert crucial functions in a wide array of physiological or pathological processes such as epigenetic regulation (Q. Yao et al., 2019), cellular proliferation (Hayashita et al., 2005), metabolism (Ye et al., 2018), homeostasis (FernandezHernando \& Suarez, 2018), differentiation (S. Yao, 2016), organogenesis, and development (Asli et al., 2008). Therefore, dysregulation of miRNAs induces various clinically important human diseases such as cancer, autoimmune disease, and cardiovascular diseases (Colpaert \& Calore, 2019; Esquela-Kerscher \& Slack, 2006). Recent studies demonstrated that miRNAs highly enriched in the heart have an important role in the mammalian cardiovascular system and heart function regulation (Jing et al., 2018; Y. Zhao et al., 2007). Alterations of miRNAs expression under the toxic effects of chemotherapy drugs could be effective in the early diagnosis and preventing or limiting of chemotherapy-induced toxicity. This suggests that identification of the potential roles and interaction networks of tissue-specific miRNAs in the heart may help to shed light on the cardiotoxicity mechanisms and may provide means to manage or prevent the side effects. Recent studies have reported that miR-129-1-3p plays a key role in anthracycline-induced cardiotoxicity through regulating calcium homeostasis (Q. Li et al., 2020). Additional in vitro and in vivo studies have implicated miR-330-5p (Han et al., 2020) and miR451 (J. Li et al., 2019) in calcium handling/DOXinduced cardiotoxicity axis. Previous studies have reported that miRNAs such as miR-34a (Hu et al., 2018), miR-146a (Horie et al., 2010), miR-208a (Callis et al., 2009), and miR-130a contribute to anthracycline toxicity. However, miR-130a has attracted considerable attention because of its validated heart-specific expression. Studies demonstrated that miR-130a expression is higher in embryonic hearts compared to adult tissue, suggesting that this miRNA is an actively modulated factor during different stages in the development of the heart (Kim et al., 2009). Moreover, recent studies also reported that the expression of miR-130a increases sharply upon DOX treatment (Huang et al., 2019; Pakravan et al., 2018). When evaluated from this perspective, an extensive understanding of the specific network of miR-130a in DOX-induced cardiotoxicity is meaningful for future treatment strategies. Therefore, miR-130a was chosen as a qualified candidate in this study to increase the sensitivity of our approach due to its heart and lung restricted expression (Lagos-Quintana et al., 2002).

In the present study, to explore the molecular mechanism of DOX-induced cardiotoxicity, the differentially expressed genes (DEGs) following doxorubicin treatment between HF (heart failure) vs non-HF samples targeted by heart-specific miRNA (hsa-miR130a-3p) were predicted and analyzed by functional and pathway enrichment analysis using microarray dataset GSE40447.

\section{Materials and methods}

\subsection{Microarray data; GEO database mining and dataset acquisition}

Cardiotoxicity-related microarray gene expression dataset [GSE40447] (McCaffrey et al., 2013) generated from the Affymetrix platform (Affymetrix Human Genome U133 Plus 2.0 Arrays; Affymetrix, Santa Clara, Ca.) was downloaded from the Gene Expression Omnibus 
(GEO)

database

(https://www.ncbi.nlm.nih.gov/geo/). Overall, 15

samples (5 women doxorubicin-induced cardiotoxicity and 10 women with chemotherapy

history but no cardiotoxicity) were enrolled in this study. The workflow of the whole study is schematized in Fig. 1.

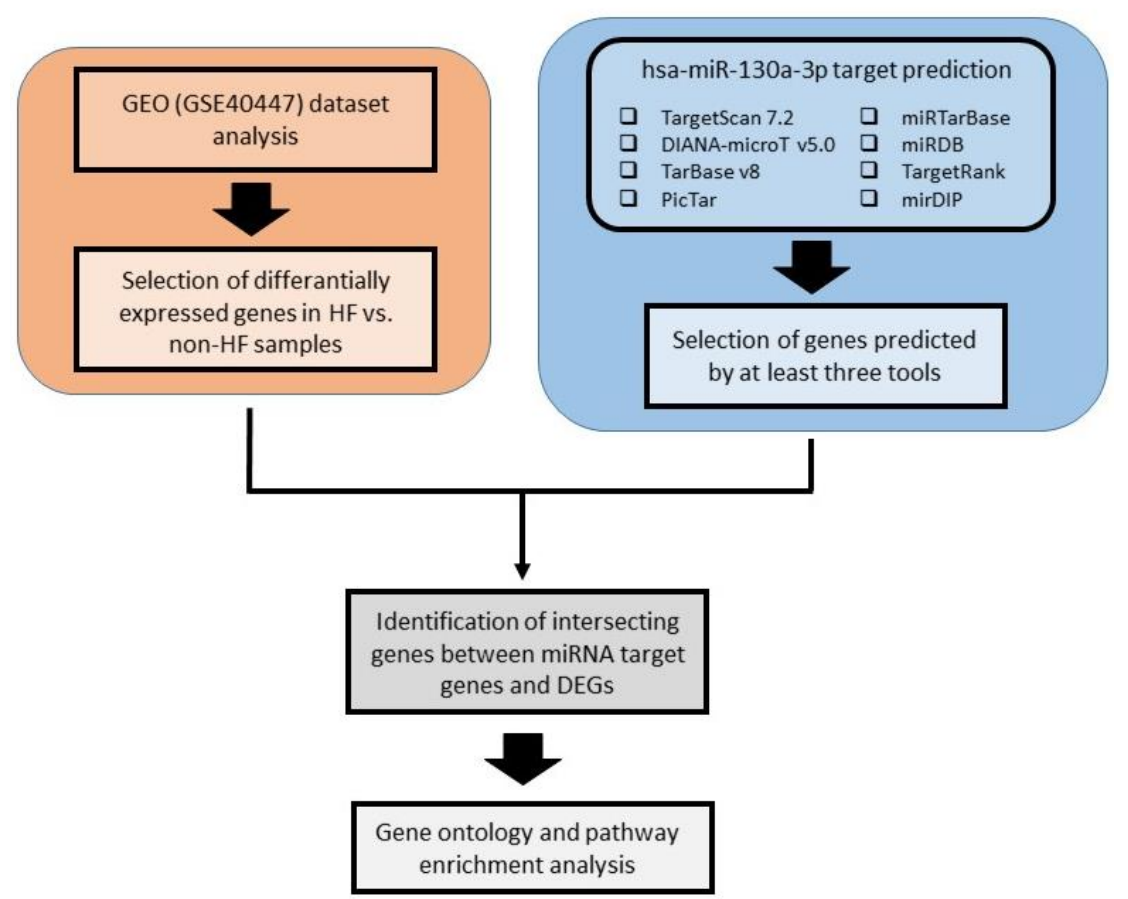

Figure 1. A flowchart depicting the outline of the study.

\subsection{Data preprocessing and differentially expressed genes analysis}

The differentially expressed genes (DEGs) associated with cardiotoxicity were obtained from GSE40447. DEGs were selected using criteria adjusted $p<0.05$ and $|\operatorname{LogFC}|>0.5$ (up and down). iPathwayGuide (Advaita Corporation, Plymouth, MI, USA) online bioinformatics tool (Draghici et al., 2007) was used for both DEG analysis and generate summary volcano plots of all DEGs for doxorubicin chemotherapy between HF vs non-HF samples.

\section{3. miRNA target prediction}

To further explore the molecular mechanisms by which hsa-miR-130a-3p involved in DOX-induced cardiotoxicity, putative miRNA:gene interactions were identified using eight in silico miRNA target prediction algorithms; TargetScan 7.2 (Agarwal et al., 2015), DIANA-microT v5.0 (Maragkakis et al., 2009), miRDB (Y. Chen \& Wang, 2020), TargetRank (Nielsen et al., 2007), DIANA TarBase v8 (Karagkouni et al., 2018), mirDIP (Tokar et al., 2018), and miRTarBase (Hsu et al., 2011). To narrow down the number of false positives, a putative gene was only considered a target if found in at least three of the eight algorithms. In this direction, a set of target mRNAs were selected between databases using The Multiple List Comparator (http://www.molbiotools.com/listcompare.html) and the InteractiVenn Venn diagram generator tool (Heberle et al., 2015).

\subsection{Gene ontology and KEGG pathway enrichment analyses of the DEGs}

To determine the intersection of miRNA-130a-3p target genes and DEGs, The Multiple List Comparator

(http://www.molbiotools.com/listcompare.html) was used. Then functional enrichment analyses were conducted separately for up and downregulated genes. To interpret the biological themes, intersecting genes were classified into GO categories using the PANTHER classification system (Thomas et al., 2003). Using the Enrichr platform (E. Y. Chen et al., 2013), Kyoto Encyclopedia of Gene and Genomes (KEGG) pathway enrichment analysis was performed. 


\section{Results}

\subsection{Identification of DEGs}

A total of 15 samples (5 doxorubicin-induced cardiotoxicity and 10 chemotherapy history but no cardiotoxicity) of the gene expression profile GSE40447 were found to be qualified for the present study. When these data were analyzed by iPathwayGuide, 601 differentially expressed genes (276 up-regulated and 325 down-regulated) were identified from a total of 17698 genes in HF compared to the non-HF group. The distribution of identified DEGs is shown in a volcano plot (Fig. 2).

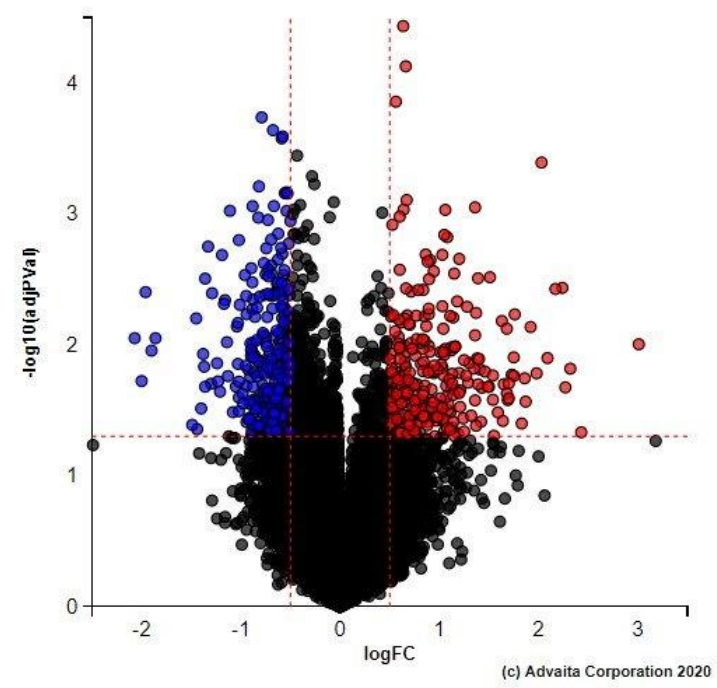

Figure 2. Volcano plot of DEGs in response to doxorubicin. The red dots represent up-regulated DEGs and blue dots represent down-regulated DEGs. Non-significant genes are shown as black dots. DEGs; differentially expressed genes.

\subsection{Downstream targets of hsa-miR-130a-3p}

The computational analysis of hsa-miR-130a-3p target genes based on the eight web-based prediction platforms identified a total of 7,018 genes. Of these, 995 genes were predicted by at least three of the algorithms. In this manner, target genes were selected more accurately and reduced false positives. To narrow down the number of the predicted target gene, intersection analysis was performed between DEGs in the GSE40447 dataset and target genes. Finally, in total 29 genes (Table 1, Fig. 3) were identified as candidate target genes for further $\mathrm{GO}$ and pathway enrichment analysis.

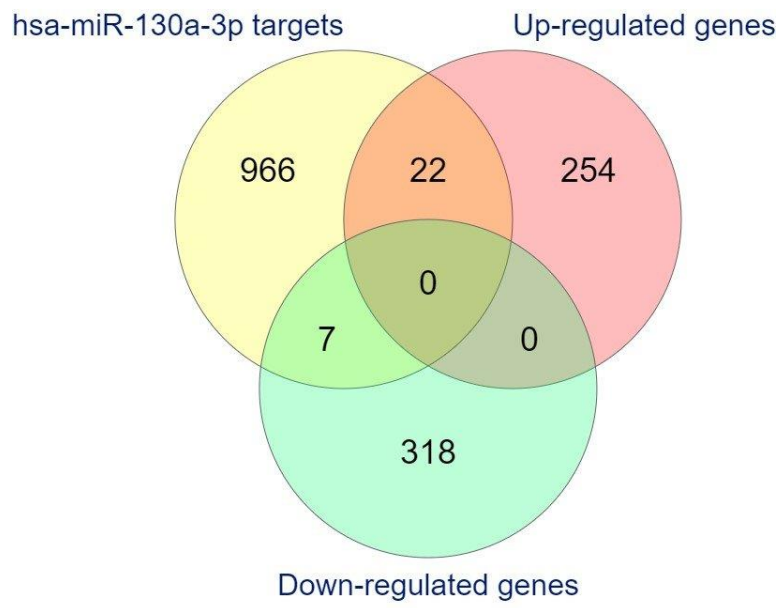

Figure 3. Venn diagram of the intersection genes between DEGs and miR-130a-3p target genes.

Table 1. List of the intersection genes between DEGs and miR-130a-3p target genes.

\begin{tabular}{ccc|c}
\hline Up-regulated DEGs targeted by miR-130a-3p & Down-regulated DEGs targeted by miR-130a-3p \\
\hline$C F L 2$ & $P M E P A 1$ & $N B E A$ & $R T N 1$ \\
$P I G A$ & ZNF614 & $P G A P 1$ & $S L C 10 A 3$ \\
$R A B 30$ & ZNF711 & ZNF567 & $S L C 24 A 3$ \\
$T R I M 2$ & $L A R P 4$ & $R A L G P S 2$ & $S L C 8 A 1$ \\
KBTBD8 & LCORL & $S C N 3 A$ & $V P S 37 B$ \\
USP6 & LIX1 & UGT8 & $C C 2 D 1 B$ \\
EPB4IL5 & MIER3 & $T A F 4 B$ & $M A P R E 3$ \\
& GTPBP10 & & \\
\hline
\end{tabular}

\subsection{Gene Ontology $(G O)$ term enrichment analysis}

The online PANTHER Gene List Analysis tool was used to GO term enrichment analysis and investigation of the functional characteristics of the 29 common DEGs. As shown in Fig. 4 and Fig. 5, the DEGs were assigned and significantly enriched in three categories; biological processes (BP), cellular component (CC), and molecular functions (MF). For BP, enrichment analysis, the results showed that the up-regulated genes took part in the cellular process (GO:0009987), metabolic process (GO:0008152), biological regulation 
(GO:0065007), cellular component organization or biogenesis (GO:0071840), localization (GO:0051179), multicellular organismal process (GO:0032501) and signaling (GO:0023052). The down-regulated DIGs were involved in the cellular process (GO:0009987), localization (GO:0051179), biological regulation (GO:0065007), metabolic process (GO:0008152), and cellular component organization or biogenesis (GO:0071840). In the GO category CC, both up and down-regulated DEGs were involved in the cell part (GO:0044464), cell (GO:0005623), organelle (GO:0043226), protein-containing complex (GO:0032991), membrane (GO:0016020), organelle part (GO:0044422), and membrane part (GO:0044425). Also, related to molecular function, these target genes appeared to mainly participate in binding (GO:0005488), transcription regulator activity (GO:0140110), and transporter activity (GO:0005215).

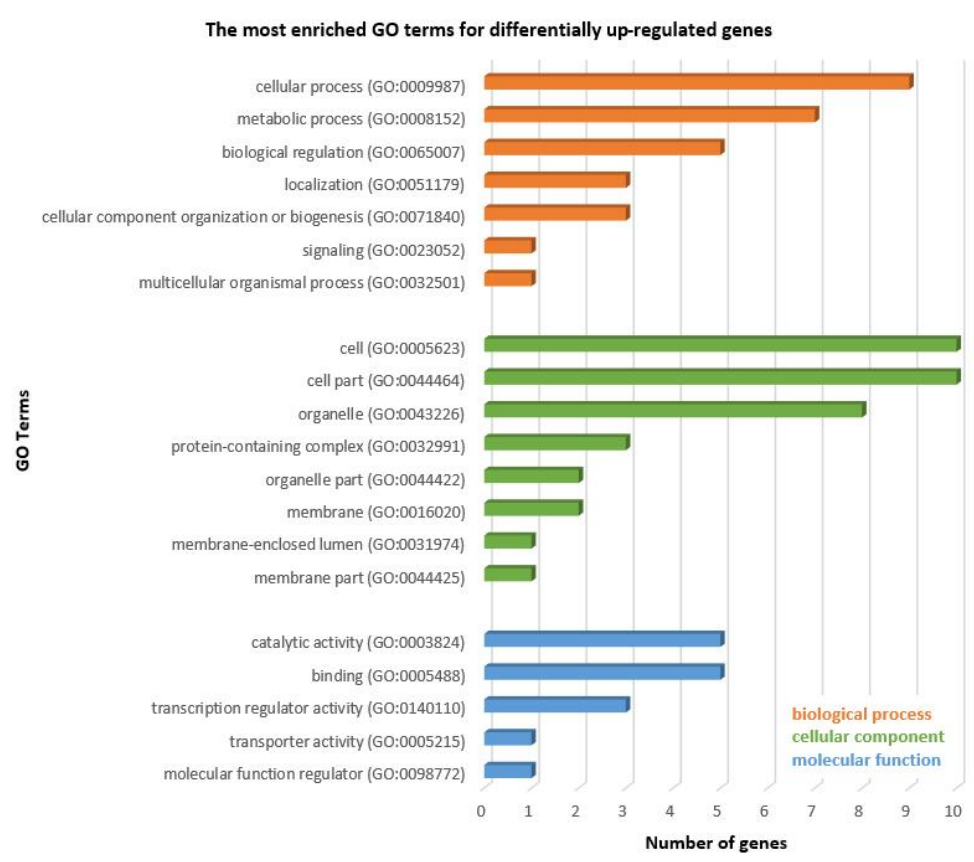

Figure 4. Gene ontology (GO) term enrichment analysis of biological processes (BP), cellular component (CC), and molecular function (MF) for up-regulated differentially expressed genes (DEGs).

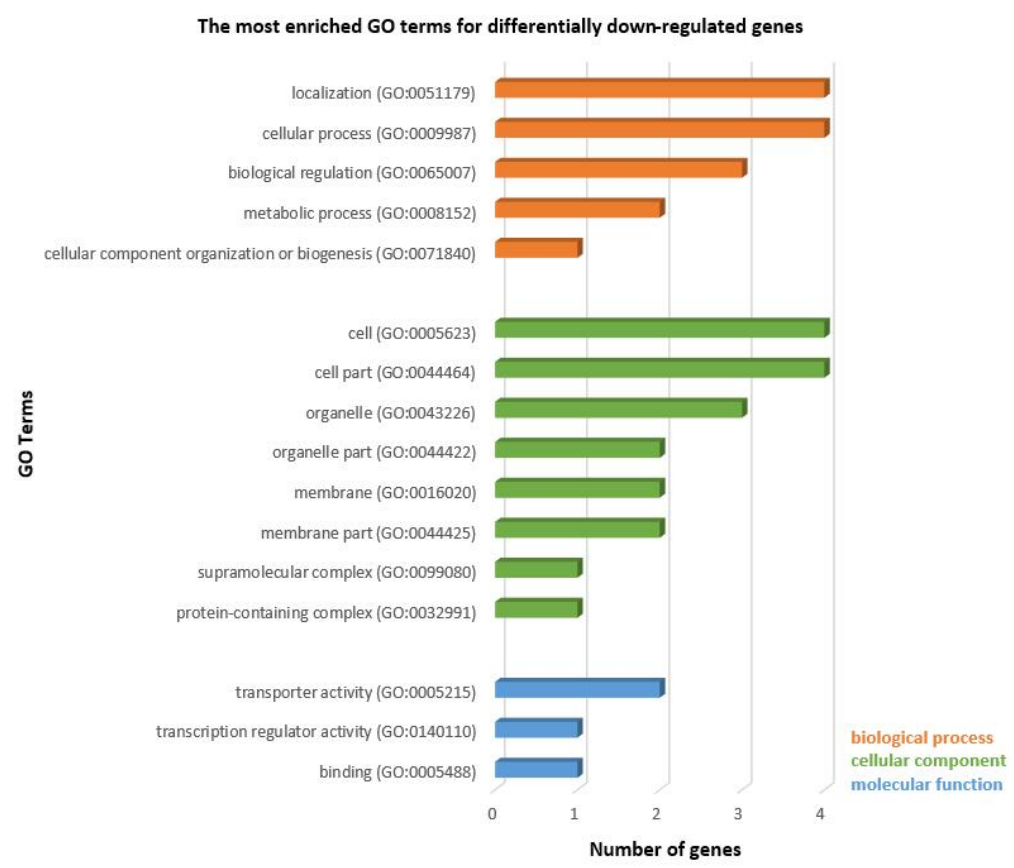

Figure 5. Gene ontology (GO) term enrichment analysis of biological processes (BP), cellular component (CC), and molecular function (MF) for down-regulated differentially expressed genes (DEGs). 


\subsection{KEGG pathway analysis}

Using the Enrichr platform KEGG pathway analysis was performed separately, for up and down-regulated genes. A total of 12 and 13 enriched were identified pathways for up-regulated and down-regulated genes, respectively. Pathway analysis showed that the up-regulated DEGs were significantly enriched in Glycosylphosphatidylinositol (GPI)-anchor biosynthesis and Basal transcription factors (Table
2), while the down-regulated DEGs were significantly enriched in Endocrine and other factor-regulated calcium reabsorption, Mineral absorption, Arrhythmogenic right ventricular cardiomyopathy (ARVC), Cardiac muscle contraction, Hypertrophic cardiomyopathy (HCM), Protein digestion and absorption, Dilated cardiomyopathy (DCM), Apelin signaling pathway and Adrenergic signaling in cardiomyocytes (Table $3)$.

Table 2. KEGG pathway enrichment analysis of up-regulated DEGs. KEGG; Kyoto Encyclopedia Analysis of Genes and Genomes.

\begin{tabular}{|c|l|c|c|c|}
\hline Index & Name & Gene(s) & $p$-value & $\begin{array}{c}\text { Combined } \\
\text { score }\end{array}$ \\
\hline $\mathbf{1}$ & $\begin{array}{l}\text { Glycosylphosphatidylinositol (GPI)- } \\
\text { anchor biosynthesis }\end{array}$ & PGAP1;PIGA & 0.0003412 & 580.58 \\
\hline $\mathbf{2}$ & Basal transcription factors & $T A F 4 B$ & 0.04837 & 61.19 \\
\hline $\mathbf{3}$ & Sphingolipid metabolism & UGT8 & 0.05047 & 57.76 \\
\hline $\mathbf{4}$ & Ether lipid metabolism & UGT8 & 0.05047 & 57.76 \\
\hline $\mathbf{5}$ & Pertussis & $C F L 2$ & 0.08039 & 30.15 \\
\hline $\mathbf{6}$ & Taste transduction & $S C N 3 A$ & 0.08747 & 26.69 \\
\hline $\mathbf{7}$ & Fc gamma R-mediated phagocytosis & $C F L 2$ & 0.09551 & 23.46 \\
\hline $\mathbf{8}$ & Axon guidance & ZNF614;ZNF567 & 0.1814 & 8.57 \\
\hline $\mathbf{9}$ & Herpes simplex virus 1 infection & $C F L 2$ & 0.1010 & 8.47 \\
\hline $\mathbf{1 0}$ & Huntington disease & $T A F 4 B$ & 0.1922 & 7.77 \\
\hline $\mathbf{1 1}$ & $\begin{array}{l}\text { Human immunodeficiency virus 1 } \\
\text { infection }\end{array}$ & $C F L 2$ & 0.2091 & 6.71 \\
\hline $\mathbf{1 2}$ & Regulation of actin cytoskeleton & $C F L 2$ & 0.2108 & 6.61 \\
\hline
\end{tabular}

Table 3. KEGG pathway enrichment analysis of down-regulated DEGs. KEGG; Kyoto Encyclopedia Analysis of Genes and Genomes.

\begin{tabular}{|c|l|c|c|c|}
\hline Index & Name & Gene(s) & $p$-value & $\begin{array}{c}\text { Combined } \\
\text { score }\end{array}$ \\
\hline $\mathbf{1}$ & $\begin{array}{l}\text { Endocrine and other factor-regulated calcium } \\
\text { reabsorption }\end{array}$ & $S L C 8 A 1$ & 0.01668 & 243.66 \\
\hline $\mathbf{2}$ & Mineral absorption & $S L C 8 A 1$ & 0.01772 & 225.95 \\
\hline $\mathbf{3}$ & $\begin{array}{l}\text { Arrhythmogenic right ventricular } \\
\text { cardiomyopathy (ARVC) }\end{array}$ & $S L C 8 A 1$ & 0.02493 & 146.49 \\
\hline $\mathbf{4}$ & Cardiac muscle contraction & $S L C 8 A 1$ & 0.02699 & 132.32 \\
\hline $\mathbf{5}$ & Hypertrophic cardiomyopathy (HCM) & $S L C 8 A 1$ & 0.02938 & 118.57 \\
\hline $\mathbf{6}$ & Protein digestion and absorption & $S L C 8 A 1$ & 0.03108 & 110.19 \\
\hline $\mathbf{7}$ & Dilated cardiomyopathy (DCM) & $S L C 8 A 1$ & 0.03142 & 108.64 \\
\hline $\mathbf{8}$ & Apelin signaling pathway & $S L C 8 A 1$ & 0.04698 & 63.77 \\
\hline $\mathbf{9}$ & Adrenergic signaling in cardiomyocytes & $S L C 8 A 1$ & 0.04967 & 59.16 \\
\hline $\mathbf{1 0}$ & cGMP-PKG signaling pathway & $S L C 8 A 1$ & 0.05668 & 49.40 \\
\hline $\mathbf{1 1}$ & Calcium signaling pathway & $S L C 8 A 1$ & 0.06398 & 41.78 \\
\hline $\mathbf{1 2}$ & Endocytosis & VPS37B & 0.08235 & 29.24 \\
\hline $\mathbf{1 3}$ & Olfactory transduction & $S L C 8 A 1$ & 0.1454 & 12.41 \\
\hline
\end{tabular}




\section{Discussion}

Doxorubicin is considered one of the most wellknown and widely used anticancer drugs in hematologic and solid tumors treatment. However, since its strong antitumor effect is accompanied by serious tissue toxicities such as cardiotoxicity, its effectiveness in cancer treatment may remain limited. Therefore, understanding the etiology of chemotherapy-induced cardiotoxicity is considered essential in terms of developing protective strategies against the development of irreversible heart damages. Although many studies have been focused on exploring the pathogenesis of cardiotoxicity, the exact molecular mechanisms of this complication development and progression remain largely unclear. In this study, we identified the hsa-miR130a-3p targeted genes in DEGs from GSE40447 and predicted key genes involved in cardiotoxicity processes.

Current medical studies have implicated that it is impossible to elucidate the source and progression of complicated diseases such as cardiotoxicity using the single gene or signaling pathway-based outcomes. Bioinformatic-based high-throughput analyses of the downstream effects of miRNAs on target genes and specific interactions of miRNAmRNA have been the core of many studies. Therefore, the integrated analysis of a miRNAdriven regulatory network that fosters cardiac function anomaly can utilize to help us clarify the understanding of gene regulations on drug-induced cardiotoxicity. This way the crucial genes involved in the disease pathogenesis can be determined, which can support revealing clinical treatment targets (Yadi et al., 2020).

Previous studies showed that anthracyclines trigger the formation of reactive oxygen species (ROS), lipid peroxidation in myocardial mitochondria membrane, and impairment of calcium homeostasis (Cappetta et al., 2017; Sawyer et al., 2010). Supporting this view, some recent studies indicate that the two major hallmarks of DOXinduced cardiotoxicity, cardiac dysfunction, and apoptosis, are impaired with calcium homeostasis (Pecoraro et al., 2017; Zhang et al., 2014). However, despite decades of intense research, the basic molecular mechanisms involved in anthracycline-induced calcium metabolism in cardiac injury remain unclear and need to be investigated. As mentioned above, disruption of mitochondrial calcium homeostasis has also been regarded as a contributory mechanism for the progression of anthracycline-induced cardiomyocyte injury Therefore, controlling calcium levels may be a critical strategy to management anthracycline-induced cardiotoxicity (Dibb et al., 2007). A growing body of evidence indicates that miRNAs are the key players in the regulation of target mRNAs hence, they seem to be a considerable tool for managing drug-induced cardiotoxicity (Pellegrini et al., 2020). Recent studies have shown that miRNAs are involved in a variety of processes in the heart such as mechanical and electrical remodeling leading to heart diseases (N. Li et al., 2018).

The purpose of the current study is to investigate the pivotal genes involved in anthracyclineinduced cardiotoxicity. In the first step, 995 mRNAs targeted by miR-130a were predicted by different algorithms. In the second step, gene expression profile GSE40447 was analyzed for the identification of differentially expressed genes in DOX-administered samples. We identified 601 DEGs (276 up and 325 down-regulated) which are possibly implicated in cardiotoxicity in patients with chemotherapy-induced cardiotoxicity compared with patients with chemotherapy history but no cardiotoxicity. These analyses revealed that there were 29 intersection genes between miR130a target mRNAs and DEGs, of which 22 genes were upregulated while 7 were downregulated, which were further subjected to gene ontology (GO) and pathway enrichment analysis, separately. The GO term enrichment analysis showed that DEGs were mainly assembled in functions like cellular process, metabolic process, localization, biological regulation, cell part, organelle, membrane part, binding, transcription regulator activity, and transporter activity. In Kyoto Encyclopedia of Genes and Genomes (KEGG) pathway analysis, the significantly enriched pathways were relevant to heart function and the cardiac system. Results revealed 11 KEGG pathways significantly changed in HF groups compared to non-HF groups (nominal $p$-value < 0.05 ), involved in signaling and metabolic processes such as Endocrine and other factorregulated calcium reabsorption, Arrhythmogenic right ventricular cardiomyopathy (ARVC), Cardiac muscle contraction, Hypertrophic cardiomyopathy (HCM), Dilated cardiomyopathy (DCM), Apelin signaling pathway, Adrenergic signaling in cardiomyocytes, and Glycosylphosphatidylinositol (GPI)-anchor biosynthesis. According to these findings, significantly enriched pathways were mainly associated with the cardiac system and functions. Thus we speculated that miR-130a-3p likely modulates the cardiotoxicity via those associated pathways. 
Interestingly, results revealed that $S L C 8 A 1$ (Solute Carrier Family 8 (Sodium/Calcium Exchanger), Member A1, also known as NCXI; sodiumcalcium exchanger 1) was represented in all significantly enriched pathways for downregulated genes which are also miR-130a-3p targets (Table 3 ). It has been known for a long time that calcium $\left(\mathrm{Ca}^{2+}\right)$ is essential for numerous physiological functions such as neuronal excitability, intracellular signaling processes (Clapham, 2007), muscle contraction (Eisner et al., 2017), and electrical activity and pumping function of the heart (Landstrom et al., 2017). The importance of calcium-associated signaling in the heart tissue has been attracted a great deal of attention for decades because impaired calcium movement pathways are directly involved in hindering normal heart functions (Eisner et al., 2020). Previous studies reported that electrical activity and digitalis action of the heart is orchestrated by $\mathrm{Na}^{+} / \mathrm{Ca}^{2+}$ exchanger exchangers such as SLC8A1 (Baartscheer, 2006). Moreover, it was also suggested that an abnormal intracellular concentration of both $\mathrm{Na}^{+}$and $\mathrm{Ca}^{2+}$ through the downregulation of SLC8A1 may explain the impaired cardiac functionality (Holmgren et al., 2018). In addition to this, doxorubicin-dependent cardiotoxicity studies also demonstrated that $\mathrm{Ca}^{2+}$-transporting genes such as CACNA1G, CACNA2D2, RYR2, ITPR1, and $S L C 8 A 1$ were downregulated after DOX treatment (Chaudhari et al., 2016). The results of the Comparative Toxicogenomics Database; CTD (http://ctdbase.org/) query also showed that the majority of the diseases associated with the SLC8A1 gene are cardiovascular diseases (data not shown). These findings suggest that $S L C 8 A 1$ is an important target gene of miR-130a-3p that contributes to cardiac pathology development. Accordingly, SLC8A1 may be evaluated as a novel therapeutic target for the prevention or treatment of detrimental cardiac events caused by doxorubicin via manipulating miR-130a-3p. Taken together, these findings support the hypothesis that SLC8A1 manipulation could be considered a novel additional molecular target and can have a strong potential benefit in treating anthracycline-induced heart disease.

\section{Conclusion}

In conclusion, despite the impressive progressions in cancer treatment strategies, several major issues about the understanding of underlying mechanisms of chemotherapy-induced cardiotoxicity remain unclear. This study identified several key genes and/or potential biomarkers in modulating and predicting the progression of cardiotoxicity. These findings may improve our knowledge about molecular mechanisms underlying chemotherapyinduced cardiotoxicity and may provide promising targets for the development of cardioprotective agents to strengthen the therapeutic efficacy of anthracycline therapy.

\section{Conflict of interest}

The author declares that there is no conflict of interest with any financial organization or corporation or individual that can inappropriately influence this work.

\section{References}

Agarwal, V., Bell, G. W., Nam, J. W. and Bartel, D. P. (2015). Predicting effective microRNA target sites in mammalian mRNAs. Elife, 4. https://doi.org/10.7554/eLife.05005

Asli, N. S., Pitulescu, M. E. and Kessel, M. (2008). MicroRNAs in organogenesis and disease. Current Molecular Medicine, 8(8), 698-710. https://doi.org/10.2174/156652408786733739

Baartscheer, A. (2006). Chronic inhibition of $\mathrm{Na}(+) / \mathrm{H}(+)$-exchanger in the heart. Current Vascular Pharmacology, 4(1), 23-29. https://doi.org/10.2174/157016106775203117

Callis, T. E., Pandya, K., Seok, H. Y., Tang, R. H., Tatsuguchi, M., Huang, Z. P., Chen, J. F., Deng, Z., Gunn, B., Shumate, J., Willis, M. S., Selzman, C. H. and Wang, D. Z. (2009). MicroRNA-208a is a regulator of cardiac hypertrophy and conduction in mice. Journal of Clinical Investigation, $\quad 119(9)$, 2772-2786. https://doi.org/10.1172/JCI36154

Cappetta, D., De Angelis, A., Sapio, L., Prezioso, L., Illiano, M., Quaini, F., Rossi, F., Berrino, L., Naviglio, S. and Urbanek, K. (2017). Oxidative stress and cellular response to doxorubicin: A common factor in the complex milieu of anthracycline cardiotoxicity. Oxidative Medicine and Cellular Longevity, 2017, 1521020. https://doi.org/10.1155/2017/1521020

Chang, D., Li, H., Qian, C. and Wang, Y. (2019). DiOHF protects against doxorubicin-induced cardiotoxicity through ERK1 signaling pathway. Front Pharmacol, 10, 1081. https://doi.org/10.3389/fphar.2019.01081

Chaudhari, U., Nemade, H., Wagh, V., Gaspar, J. A., Ellis, J. K., Srinivasan, S. P., Spitkovski, D., Nguemo, F., Louisse, J., Bremer, S., Hescheler, J., Keun, H. C., Hengstler, J. G. and Sachinidis, A. (2016). Identification of genomic biomarkers for anthracycline-induced cardiotoxicity in human iPSC-derived cardiomyocytes: an in vitro 
repeated exposure toxicity approach for safety assessment. Archives of Toxicology, 90(11), 2763-2777. https://doi.org/10.1007/s00204-0151623-5

Chen, E. Y., Tan, C. M., Kou, Y., Duan, Q., Wang, Z., Meirelles, G. V., Clark, N. R. and Ma'ayan, A. (2013). Enrichr: interactive and collaborative HTML5 gene list enrichment analysis tool. BMC Bioinformatics, $14, \quad 128$. https://doi.org/10.1186/1471-2105-14-128

Chen, Y. and Wang, X. (2020). miRDB: an online database for prediction of functional microRNA targets. Nucleic Acids Research, 48(D1), D127D131. https://doi.org/10.1093/nar/gkz757

Clapham, D. E. (2007). Calcium signaling. Cell, 131(6), 1047-1058.

https://doi.org/10.1016/j.cell.2007.11.028

Colpaert, R. M. W. and Calore, M. (2019). MicroRNAs in cardiac diseases. Cells, 8(7). https://doi.org/10.3390/cells8070737

Deiuliis, J. A. (2016). MicroRNAs as regulators of metabolic disease: pathophysiologic significance and emerging role as biomarkers and therapeutics. International Journal of Obesity, 40(1), 88-101. https://doi.org/10.1038/ijo.2015.170

Dibb, K. M., Graham, H. K., Venetucci, L. A., Eisner, D. A. and Trafford, A. W. (2007). Analysis of cellular calcium fluxes in cardiac muscle to understand calcium homeostasis in the heart. Cell Calcium, 42(4-5), 503-512. https://doi.org/10.1016/j.ceca.2007.04.002

Draghici, S., Khatri, P., Tarca, A. L., Amin, K., Done, A., Voichita, C., Georgescu, C. and Romero, R. (2007). A systems biology approach for pathway level analysis. Genome Research, 17(10), 15371545. https://doi.org/10.1101/gr.6202607

Eisner, D. A., Caldwell, J. L., Kistamas, K. and Trafford, A. W. (2017). Calcium and excitationcontraction coupling in the heart. Circulation Research, 121(2), 181-195. https://doi.org/10.1161/CIRCRESAHA.117.310 230

Eisner, D. A., Caldwell, J. L., Trafford, A. W. and Hutchings, D. C. (2020). The control of diastolic calcium in the heart: Basic mechanisms and functional implications. Circulation Research 126(3),

395-412. https://doi.org/10.1161/CIRCRESAHA.119.315 891

Esquela-Kerscher, A. and Slack, F. J. (2006). Oncomirs - microRNAs with a role in cancer. Nature Reviews Cancer, 6(4), 259-269. https://doi.org/10.1038/nrc1840
Fernandez-Hernando, C. and Suarez, Y. (2018). MicroRNAs in endothelial cell homeostasis and vascular disease. Curr Opin Hematol, 25(3), 227236. https://doi.org/10.1097/MOH.00000000000004 24

Gennari, A., Sormani, M. P., Pronzato, P., Puntoni, M., Colozza, M., Pfeffer, U. and Bruzzi, P. (2008). HER2 status and efficacy of adjuvant anthracyclines in early breast cancer: a pooled analysis of randomized trials. J Natl Cancer Inst, 100(1), 14-20. https://doi.org/10.1093/jnci/djm252

Gomez, I. G., Nakagawa, N. and Duffield, J. S. (2016). MicroRNAs as novel therapeutic targets to treat kidney injury and fibrosis. Am J Physiol Renal Physiol, 310(10), F931-944. https://doi.org/10.1152/ajprenal.00523.2015

Han, D., Wang, Y., Wang, Y., Dai, X., Zhou, T., Chen, J., Tao, B., Zhang, J. and Cao, F. (2020). The tumor-suppressive human circular RNA CircITCH Sponges miR-330-5p to ameliorate doxorubicin-induced cardiotoxicity through upregulating SIRT6, survivin, and SERCA2a. Circ Res, 127(4), e108-e125. https://doi.org/10.1161/CIRCRESAHA.119.316 061

Hayashita, Y., Osada, H., Tatematsu, Y., Yamada, H., Yanagisawa, K., Tomida, S., Yatabe, Y., Kawahara, K., Sekido, Y. and Takahashi, T. (2005). A polycistronic microRNA cluster, miR17-92, is overexpressed in human lung cancers and enhances cell proliferation. Cancer Res, 65(21), 9628-9632. https://doi.org/10.1158/0008-5472.CAN-052352

Heberle, H., Meirelles, G. V., da Silva, F. R., Telles, G. P. and Minghim, R. (2015). InteractiVenn: a web-based tool for the analysis of sets through Venn diagrams. BMC Bioinformatics, 16, 169. https://doi.org/10.1186/s12859-015-0611-3

Holmgren, G., Sartipy, P., Andersson, C. X., Lindahl, A. and Synnergren, J. (2018). Expression profiling of human pluripotent stem cell-derived cardiomyocytes exposed to doxorubicinintegration and visualization of multi-omics data. Toxicol Sci, 163(1), 182-195. https://doi.org/10.1093/toxsci/kfy012

Hooning, M. J., Botma, A., Aleman, B. M., Baaijens, M. H., Bartelink, H., Klijn, J. G., Taylor, C. W. and van Leeuwen, F. E. (2007). Long-term risk of cardiovascular disease in 10-year survivors of breast cancer. J Natl Cancer Inst, 99(5), 365-375. https://doi.org/10.1093/jnci/djk064

Horie, T., Ono, K., Nishi, H., Nagao, K., Kinoshita, M., Watanabe, S., Kuwabara, Y., Nakashima, Y., 
Takanabe-Mori, R., Nishi, E., Hasegawa, K., Kita, T. and Kimura, T. (2010). Acute doxorubicin cardiotoxicity is associated with miR-146a-induced inhibition of the neuregulinErbB pathway. Cardiovasc Res, 87(4), 656-664. https://doi.org/10.1093/cvr/cvq148

Hsu, S. D., Lin, F. M., Wu, W. Y., Liang, C., Huang, W. C., Chan, W. L., Tsai, W. T., Chen, G. Z., Lee, C. J., Chiu, C. M., Chien, C. H., Wu, M. C., Huang, C. Y., Tsou, A. P. and Huang, H. D. (2011). miRTarBase: a database curates experimentally validated microRNA-target interactions. Nucleic Acids Res, 39(Database issue), D163-169. https://doi.org/10.1093/nar/gkq1107

Hu, Y., Xia, W. and Hou, M. (2018). Macrophage migration inhibitory factor serves a pivotal role in the regulation of radiation-induced cardiac senescencethrough rebalancing the microRNA34a/sirtuin 1 signaling pathway. Int J Mol Med, 42(5), 2849-2858. https://doi.org/10.3892/ijmm.2018.3838

Huang, J., Zhao, M., Hu, H., Wang, J., Ang, L. and Zheng, L. (2019). MicroRNA-130a reduces drug resistance in breast cancer. Int J Clin Exp Pathol, 12(7), 2699-2705.

Jing, X., Yang, J., Jiang, L., Chen, J. and Wang, H. (2018). MicroRNA-29b Regulates the mitochondria-dependent apoptotic pathway by targeting bax in doxorubicin cardiotoxicity. Cell Physiol Biochem, 48(2), 692-704. https://doi.org/10.1159/000491896

Karagkouni, D., Paraskevopoulou, M. D., Chatzopoulos, S., Vlachos, I. S., Tastsoglou, S., Kanellos, I., Papadimitriou, D., Kavakiotis, I., Maniou, S., Skoufos, G., Vergoulis, T., Dalamagas, T. and Hatzigeorgiou, A. G. (2018). DIANA-TarBase v8: a decade-long collection of experimentally supported miRNA-gene interactions. Nucleic Acids Res, 46(D1), D239D245. https://doi.org/10.1093/nar/gkx1141

Kim, G. H., Samant, S. A., Earley, J. U. and Svensson, E. C. (2009). Translational control of FOG-2 expression in cardiomyocytes by microRNA130a. PLoS One, 4(7), e6161. https://doi.org/10.1371/journal.pone.0006161

Lagos-Quintana, M., Rauhut, R., Yalcin, A., Meyer, J., Lendeckel, W. and Tuschl, T. (2002). Identification of tissue-specific microRNAs from mouse. Curr Biol, 12(9), 735-739. https://doi.org/10.1016/s0960-9822(02)00809-6

Landstrom, A. P., Dobrev, D. and Wehrens, X. H. T. (2017). Calcium signaling and cardiac arrhythmias. Circ Res, 120(12), 1969-1993. https://doi.org/10.1161/CIRCRESAHA.117.310 083
Li, J., Wan, W., Chen, T., Tong, S., Jiang, X. and Liu, W. (2019). miR-451 Silencing inhibited doxorubicin exposure-induced cardiotoxicity in mice. Biomed Res Int, 2019, 1528278. https://doi.org/10.1155/2019/1528278

Li, N., Zhou, H. and Tang, Q. (2018). miR-133: A suppressor of cardiac remodeling? Front Pharmacol, 9, 903. https://doi.org/10.3389/fphar.2018.00903

Li, Q., Qin, M., Tan, Q., Li, T., Gu, Z., Huang, P. and Ren, L. (2020). MicroRNA-129-1-3p protects cardiomyocytes from pirarubicin-induced apoptosis by down-regulating the GRIN2Dmediated $\mathrm{Ca}(2+)$ signalling pathway. J Cell Mol Med, 24(3), 2260-2271. https://doi.org/10.1111/jcmm.14908

Luminari, S., Montanini, A. and Federico, M. (2011). Anthracyclines: a cornerstone in the management of non-Hodgkin's lymphoma. Hematol Rep, 3(3s), e4. https://doi.org/10.4081/hr.2011.s3.e4

Maragkakis, M., Reczko, M., Simossis, V. A., Alexiou, P., Papadopoulos, G. L., Dalamagas, T., Giannopoulos, G., Goumas, G., Koukis, E., Kourtis, K., Vergoulis, T., Koziris, N., Sellis, T., Tsanakas, P. and Hatzigeorgiou, A. G. (2009). DIANA-microT web server: elucidating microRNA functions through target prediction. Nucleic Acids Res, 37(Web Server issue), W273276. https://doi.org/10.1093/nar/gkp292

McCaffrey, T. A., Tziros, C., Lewis, J., Katz, R., Siegel, R., Weglicki, W., Kramer, J., Mak, I. T., Toma, I., Chen, L., Benas, E., Lowitt, A., Rao, S., Witkin, L., Lian, Y., Lai, Y., Yang, Z. and Fu, S. W. (2013). Genomic profiling reveals the potential role of TCL1A and MDR1 deficiency in chemotherapy-induced cardiotoxicity. Int $J$ Biol Sci, 9(4), 350-360. https://doi.org/10.7150/ijbs.6058

McGowan, J. V., Chung, R., Maulik, A., Piotrowska, I., Walker, J. M. and Yellon, D. M. (2017). Anthracycline chemotherapy and cardiotoxicity. Cardiovasc Drugs Ther, 31(1), 63-75. https://doi.org/10.1007/s10557-016-6711-0

Melguizo, C., Cabeza, L., Prados, J., Ortiz, R., Caba, O., Rama, A. R., Delgado, A. V. and Arias, J. L. (2015). Enhanced antitumoral activity of doxorubicin against lung cancer cells using biodegradable poly(butylcyanoacrylate) nanoparticles. Drug Des Devel Ther, 9, 64336444. https://doi.org/10.2147/DDDT.S92273

Nielsen, C. B., Shomron, N., Sandberg, R., Hornstein, E., Kitzman, J. and Burge, C. B. (2007). Determinants of targeting by endogenous and exogenous microRNAs and siRNAs. RNA, 13(11), 1894-1910. https://doi.org/10.1261/rna.768207 
Pakravan, G., Foroughmand, A. M., Peymani, M., Ghaedi, K., Hashemi, M. S., Hajjari, M. and Nasr-Esfahani, M. H. (2018). Downregulation of miR-130a, antagonized doxorubicin-induced cardiotoxicity via increasing the PPARgamma expression in mESCs-derived cardiac cells. Cell Death Dis, 9(7), 758. https://doi.org/10.1038/s41419-018-0797-1

Pecoraro, M., Rodriguez-Sinovas, A., Marzocco, S., Ciccarelli, M., Iaccarino, G., Pinto, A. and Popolo, A. (2017). Cardiotoxic Effects of shortterm doxorubicin administration: Involvement of connexin 43 in calcium impairment. Int $\mathrm{J} \mathrm{Mol}$ Sci, 18(10).

https://doi.org/10.3390/ijms18102121

Pellegrini, L., Sileno, S., D'Agostino, M., Foglio, E., Florio, M. C., Guzzanti, V., Russo, M. A., Limana, F. and Magenta, A. (2020). MicroRNAs in cancer treatment-induced cardiotoxicity. Cancers (Basel), 12(3). https://doi.org/10.3390/cancers12030704

Sawyer, D. B., Peng, X., Chen, B., Pentassuglia, L. and Lim, C. C. (2010). Mechanisms of anthracycline cardiac injury: can we identify strategies for cardioprotection? Prog Cardiovasc Dis, 53(2), 105-113.

https://doi.org/10.1016/j.pcad.2010.06.007

Songbo, M., Lang, H., Xinyong, C., Bin, X., Ping, Z. and Liang, S. (2019). Oxidative stress injury in doxorubicin-induced cardiotoxicity. Toxicol Lett, $\quad 307$, 41-48. https://doi.org/10.1016/j.toxlet.2019.02.013

Thomas, P. D., Campbell, M. J., Kejariwal, A., Mi, H., Karlak, B., Daverman, R., Diemer, K., Muruganujan, A. and Narechania, A. (2003). PANTHER: a library of protein families and subfamilies indexed by function. Genome Res, 13(9), 2129-2141. https://doi.org/10.1101/gr.772403

Tokar, T., Pastrello, C., Rossos, A. E. M., Abovsky, M., Hauschild, A. C., Tsay, M., Lu, R. and Jurisica, I. (2018). mirDIP 4.1-integrative database of human microRNA target predictions. Nucleic Acids Res, 46(D1), D360-D370. https://doi.org/10.1093/nar/gkx1144
Volkova, M. and Russell, R., 3rd. (2011). Anthracycline cardiotoxicity: prevalence, pathogenesis and treatment. Curr Cardiol Rev, 7(4), 214-220. https://doi.org/10.2174/157340311799960645

Wallace, K. B. (2007). Adriamycin-induced interference with cardiac mitochondrial calcium homeostasis. Cardiovasc Toxicol, 7(2), 101-107. https://doi.org/10.1007/s12012-007-0008-2

Yadi, W., Shurui, C., Tong, Z., Suxian, C., Qing, T. and Dongning, H. (2020). Bioinformatic analysis of peripheral blood miRNA of breast cancer patients in relation with anthracycline cardiotoxicity. BMC Cardiovasc Disord, 20(1), 43. https://doi.org/10.1186/s12872-020-01346-y

Yao, Q., Chen, Y. and Zhou, X. (2019). The roles of microRNAs in epigenetic regulation. Curr Opin Chem Biol, 51, 11-17. https://doi.org/10.1016/j.cbpa.2019.01.024

Yao, S. (2016). MicroRNA biogenesis and their functions in regulating stem cell potency and differentiation. Biol Proced Online, 18, 8. https://doi.org/10.1186/s12575-016-0037-y

Ye, J., Zou, M., Li, P. and Liu, H. (2018). MicroRNA regulation of energy metabolism to induce chemoresistance in cancers. Technol Cancer Res Treat, 17, 1533033818805997. https://doi.org/10.1177/1533033818805997

Zhang, Y., Chen, Y., Zhang, M., Tang, Y., Xie, Y., Huang, X. and Li, Y. (2014). Doxorubicin induces sarcoplasmic reticulum calcium regulation dysfunction via the decrease of SERCA2 and phospholamban expressions in rats. Cell Biochem Biophys, 70(3), 1791-1798. https://doi.org/10.1007/s12013-014-0130-2

Zhao, L. and Zhang, B. (2017). Doxorubicin induces cardiotoxicity through upregulation of death receptors mediated apoptosis in cardiomyocytes. $\begin{array}{llll}\text { Sci Rep, } & \text { 7, }\end{array}$ https://doi.org/10.1038/srep44735

Zhao, Y., Ransom, J. F., Li, A., Vedantham, V., von Drehle, M., Muth, A. N., Tsuchihashi, T., McManus, M. T., Schwartz, R. J. and Srivastava, D. (2007). Dysregulation of cardiogenesis, cardiac conduction, and cell cycle in mice lacking miRNA-1-2. Cell, 129(2), 303-317. https://doi.org/10.1016/j.cell.2007.03.030 